\title{
THE PERFORMANCE ANALYSIS OF FUNCTIONAL AND RECONFIGURED LAYOUT BY MINIMISING INTERCELLULAR MOVEMENT: A CASE STUDY OF INDIAN SME
}

\author{
Pravin S. Pachpor ${ }^{1 *}$ and Rakesh L. Shrivastava ${ }^{2}$ \\ ${ }^{1}$ Department of Mechanical Engineering, Kavikulguru Institute of Technology and Science Ramtek, \\ Rastrasant Tukdoji Maharaj, Nagpur University, Nagpur, India-441106. \\ ${ }^{2}$ Department of Mechanical Engineering, Yeshwantrao Chavan College of Engineering, Nagpur, India. \\ "Corresponding e-mail: pravinpachpor@gmail.com
}

\begin{abstract}
Group technology (GT) utilizes a philosophy that involves grouping of components having similar manufacturing and design attributes, known as part families $(P F)$. In a job shop (JS) products are processed in smaller batches and with the products are changed the new processing sequence increases /changes material handling within JS. Hence to reduce material handling machines need to be arranged in cells so that most of family members can be manufactured within the cell referred as Cellular manufacturing (CM), which is one of the application of GT. The main goal of this research work is to present a performance comparison of functional JS of small medium enterprise (SME) with the objective to decrease intracellular movement of parts using newly developed approach. Effectiveness of reconfigured JS due to the proposed method and the functional layout is compared using six well known measures.
\end{abstract}

Keywords: cellular layout, machine - component cells, group technology, material handling movement.

\section{INTRODUCTION}

Group technology (GT) utilizes the concept of commonality between production processes and parts to be processed in a manufacturing unit (MU). It is a philosophy that involves recognizing and grouping components having similar manufacturing and design attributes known as part families $(\mathrm{PF})$ in order to achieve the benefit of producing them with reduced work-in-process inventory, material handling cost, throughput time, etc. Cellular manufacturing $(\mathrm{CM})$ is one of the application of GT principles to manufacturing. For each PF, required machines are arranged together to form a machine cell or a manufacturing cell, and most family members can be manufactured within the cell. This kind of layout design problem is referred to as the cellular manufacturing problem (CMP). CM emerged as a production strategy capable of solving the problems of complexity and long manufacturing lead times in batch production. The fundamental problem in $\mathrm{CM}$ is the formation of product families and machine cells.

One of the key reason that a manufacturing unit performs well when the facilities are arranged scientifically. Always the back tracking moves must be minimised.. The study presented here applies cell formation technique based on machine - component processing association to the functional machine arrangement in a JS of a small medium enterprise (SMEs) in India to minimize the material handling movement. The outcome of study is formation of machine - component cells as the initial solution. Thereafter the initial solution is modified suitably and other performance parameters along with material handling movements are checked. The study clearly indicates the group efficacy and efficiency measures are improved due to proposed methodology remark-ably. The method suggested in the proposed work can be easily used by the leading practitioners.

\section{LITERATURE REVIEW}

Number of papers are published on the cell formation techniques. Some of the published work related to the cell formation is reviewed here. Adil et al. ${ }^{1}$ have proposed method based on non linear programming for cell formation. Zhao and $\mathrm{Wu}^{2}$ minimized parts holding cost and intercellular movements with good balance of machine and cell utilization. Kim et al. ${ }^{3}$ have proposed a heuristic technique for cell formation problem. The objective was to minimize intercellular movements and machine workload imbalance. Hachicha et al. ${ }^{4}$ have proposed a correlation analysis approach of cell formation in view of minimizing the total processing time outside the cells, including production parameters. The approach is two phased i.e. grouping based on correlation in first phase and Principal Component Analysis (PCA) used for cluster analysis to form machine groups and part families at the same time. Megala et al. ${ }^{5}$ proposed an ant colony algorithm for cell-formation. The objective was to maximize the group efficacy. Praveen et al. ${ }^{6}$ have suggested four fold new approach for cell formation that amalgamate machine grouping and layout design regardless of initial part-family formation. Co and Egibelu ${ }^{7}$ have proposed method of cell formation for suitable for the changes in product demand in volume or design with time. The cells are referred as virtual cellular manufacturing system. Sofianopoulou ${ }^{8}$ proposed 
a genetic algorithm approach with the aim of least interaction between cells and also accounting for sequences of machining. Manzini et al. ${ }^{9}$ have proposed similarity coefficient based method based on a threshold value which was obtained through percentile-based cut value. Jayachitra and Prasad ${ }^{10}$ have also compared the performance of existing and suggested layout through a simulation technique. The virtual model representing the industry is created through the use of WITNESS 2006 . The results proved the suggested virtual layout to be cost effective. Shahrul et al. ${ }^{11}$ have also illustrated the effect of design of layout through checking the performance of all the three cellular, flow line, and job shop layout. The results shown the performance of flow line, job shop and cellular layout is changed due to layout design. Kumar et al. ${ }^{12}$ have suggested heuristic method for the issues associated to layout design. The method considers unidirectional flow of material, avoiding back-tracking and emphasizing the distance traveled by the components to be minimum. Ying et al. $^{13}$, have suggested, a simulated annealingbased meta-heuristic technique which considers variable neighbourhood to form part-machine cells. The results were obtained through experimentation on real life data sets. Mahdavi et al. ${ }^{14}$ have suggested the methodology for formation of virtual cells by considering in variations in part volume and in component mix for different time periods. The worker flexibility was also considered. Farahani and Hosseini ${ }^{15}$ have proposed an efficient algorithm for machine- component problems aiming for improving grouping efficacy. Use of information from similarity of processing of components is made for forming the part families. Mathur et al. ${ }^{16}$ have suggested improvement in productivity in a SME using scheduling heuristic via case study. Elbenani and Ferland ${ }^{17}$ have proposed method based on a linear binary programming formulation which provides quality results. Solutions generated by the proposed method were compared with that of obtained by other researchers from literature. Shahram et al. ${ }^{18}$ investigated effects of ambiguity in exact demand of products on the layout in a cellular manufacturing system. The focus of study was minimization of cost of material handling within and outside the cells. The use of optimization software was done for the same. Saravanan and Arulkumar $^{19}$ minimized the intercellular movement of parts by comparing two methods named as Genetic Algorithm (GA) and Simulated Annealing Algorithm (SAA). The emphasis was also given to the parts to be manufactured in large volume, minimum back tracking of parts and parts requiring more safety. Masmoudi and Hachicha ${ }^{20}$ have suggested that the cell formation technique without due consideration to real life situations are unsuitable for implementation. Hence by providing importance to parameters like maximum number of machines in a cell and cost associated with alternative actions to eliminate the exceptional elements (EE) so as to form better machinecomponent cells was demonstrated. How-ever none of the studies have revealed clear usage of their methods for the easier adoption by manu-facturer.

The study presented here is to provide solution for enhancing the productivity in a SME through reconfiguration of the functional layout of machines through newly developed algorithm for the formation of machine- component cells. Various steps involved in the study are described in subsequent sections of this paper.

\section{AIM OF THE STUDY}

Determining the scope of improvement in productivity of a JS through conversion into a cellular layout by application of newly developed approach .

\section{THE DETAILS OF THE STUDY}

The study is done at SME named ' $\mathrm{M} / \mathrm{s}$ Kinetic Gears'. The initial incidence matrix of machine and components is developed through their association known from route sheets of components. For the sake of study the number of components, machines considered are $\mathbf{1 7}$ and $\mathbf{2 1}$ respectively. Some work stations are manual such as deburring, cleaning of components, packing etc. Some of the components need heat treatments and machining which are carried out at M/s Heat Treat Well and M/s Garuda Yantra Nirmiti. (Another nearby units owned by same owner) by transporting manually from 'M/s Kinetic Gears' so as to meet the master production schedule. The quantity to be produced is decided as per the orders received from the clients. The manufacturing is done as per job shop or in batches of suitable size. Names of the jobs being processed and undertaken processes are shown in Table 1 and 2 respectively. These components are manufactured for the automotive units.

\section{METHODOLOGY}

The stepwise procedure applied for determination of cells formed due to proposed method is elaborated in this section.

\section{Step I: The development of incidence matrix}

The initial incidence matrix showing the machining requirements of machine and components is developed through their association known from route sheets of components. The developed incidence matrix is shown in Fig. 1.

For each process ' 1 ' is entered in the matrix for associated component and machine link. If component is not processed by certain machine 
then it is denoted by ' 0 ' in the matrix. The size of relationship matrix is $[\mathrm{n} \times \mathrm{m}]$, if $\mathrm{n}$ is no. of components and $\mathrm{m}$ is no. of machines.

Table 1. List of components.

\begin{tabular}{|c|l|}
\hline S. no. & Name of the component \\
\hline 1 & Detend plunger \\
\hline 2 & Washer Output flange \\
\hline 3 & Split Ring \\
\hline 4 & Selector plate \\
\hline 5 & Driver plate \\
\hline 6 & Out put flange \\
\hline 7 & Elbow \\
\hline 8 & Tachopinion \\
\hline 9 & Speedo shaft \\
\hline 10 & Seat check valve \\
\hline 11 & Relief Valve Spring Housing. \\
\hline 12 & Joint Pin \\
\hline 13 & Pin Shackle Rear \\
\hline 14 & Constant Mesh \\
\hline 15 & Driver \\
\hline 16 & Washer \\
\hline 17 & Speedometer Worm \\
\hline
\end{tabular}

$\left.\begin{array}{|l}0000000000001000 \\ 0000000000010000 \\ 0000000000100000 \\ 0000000001010010 \\ 00000000011110010 \\ 00000000011010010 \\ 00000000100100000 \\ 00000001100101000 \\ 00000001000001000 \\ 0000001000000000 \\ 0000001000000000 \\ 0000010000000010 \\ 00000100000000100 \\ 11111111111101011 \\ 11111111111111111 \\ 00111000100000001 \\ 10100000100100000 \\ 11111001111110111 \\ 1100011000000000 \\ 1111111000000000 \\ 11100111000001101\end{array}\right]$

Figure 1. The Incidence matrix (after Step I).

Step II:

Set $\mathrm{i}=0$, i.e. no component is in process.

Set $\mathrm{i}=\mathrm{i}+1$, identify the machine/machines which visit/visits the ' $i$ ' th component. If the link is established (i.e. the entry of one for $(i+1)$ th component) calculate the coefficient of relationship defined as, $R_{i j}=\frac{\mathrm{NCE}_{\mathrm{ij}}}{\mathrm{TME}_{\mathrm{ij}}}$

where, $\mathrm{NCE}_{\mathrm{ij}}=$ No. of ' 1 's' common entries for $\mathrm{i}^{\text {th }}$ component and $\mathrm{j}^{\text {th }}$ machine.

$\mathrm{TNE}_{\mathrm{ij}}=$ Total no. of non-zero entries for $\mathrm{i}^{\text {th }}$ compo-nent and $\mathrm{j}^{\text {th }}$ machine.

If $\mathrm{R}_{\mathrm{ij}}=1, \mathrm{i}^{\text {th }}$ component visits $\mathrm{j}^{\text {th }}$ machine only and vice versa.
$\mathrm{R}_{\mathrm{ij}}=0, \mathrm{i}^{\text {th }}$ component do not visit the $\mathrm{j}^{\text {th }}$ machine at all.

Such $\mathrm{R}_{\mathrm{ij}}$ values for each non-zero entries in incidence matrix are calculated.

Table 2. Undertaken processes.

\begin{tabular}{|c|l|}
\hline S. no. & Name of process /workstation \\
\hline 1 & Gear rolling \\
\hline 2 & Tempering \\
\hline 3 & Straightening \\
\hline 4 & Quenching \\
\hline 5 & Cleaning by hot water \\
\hline 6 & Binding by wire \\
\hline 7 & Turret lathe \\
\hline 8 & Deburring \\
\hline 9 & Gear hobbing \\
\hline 10 & Furnace \\
\hline 11 & Band saw machine \\
\hline 12 & Phosphating \\
\hline 13 & Broaching \\
\hline 14 & Packing and dispatch \\
\hline 15 & Inspection \\
\hline 16 & Milling \\
\hline 17 & Grinding \\
\hline 18 & Heat treatment \\
\hline 19 & Drilling \\
\hline 20 & Punching machine \\
\hline 21 & Turning on CNC lathe. \\
\hline
\end{tabular}

Step III:

All the values of $R_{i j}$ calculated in step 2 are entered in a matrix of $\left[R_{i j}\right]$, for which no. of rows (i) $=n$ and no. of columns (j) $=m$

Step IV:

(a) Select the maximum value of $R_{i j}$ from the matrix $\left[\mathrm{R}_{\mathrm{ij}}\right]$, and select the corresponding component-machine link, in case of equal values of $\mathrm{R}_{\mathrm{ij}}$ coefficient select one of them arbitrarily.

(b) Draw a horizontal and vertical line through selected value of $\mathrm{R}_{\mathrm{ij}}$. Identify the non-zero entries on the vertical line. Select the next maximum value of $R_{i j}$ in the vertical line. In case of tie between maximum value and next maximum value (or between next maximum values) select any one arbitrarily. Draw a horizontal line passing through selected next maximum value and select the associated component. Link this component to link selected in sub step 'a'.

In case of all zero values on vertical line omit this step and proceed as given below.

(c) Select the next maximum value of $R_{i j}$ from the non-zero $R_{i j}$ values on the horizontal line of latest selected component. In case of tie select any one value of $\mathrm{R}_{\mathrm{ij}}$ arbitrarily. Draw a vertical line passing through the latest selected $R_{i j}$ value and select the associated machine. Link the machine 
selected with latest link selected in sub step ' $a$ ' /'b' whichever selected later.

Go on selecting the machine and component till linkage is continued but once selected machine or component should not be selected again.

If first link breaks before selecting all component/machines indicates first cell or $\mathrm{s}$ cell formed consisting of selected machines/components and repeat the procedure from sub step ' $a$ ' after formation of each cell and there is no intercellular movement of components.

If a continuous link, consisting of all machine/s and component/s is obtained than it indicates that cells can't be separated due to presence of exceptional component/s.

Step V:

Reposition the components column wise and machines row wise in a matrix as obtained during selection process or cell formation process. This matrix is called as resulting matrix. Make the entries of 'one's' of each corresponding component-machines from the relationship matrix obtained in step 1 .

The output is expected to form a block diagonlized matix if exceptional components are absent.

Step VI:

The formed machine - components cells, associated analysis and resulting matrix obtained after the step II as a resulting file is shown in Fig. 2 along with initial incidence matrix.

\section{Step VII:}

Checking grouping efficiency and other performance measures.

In view of results analysis following performance measures are used.

i) Total number of 'Exceptional Elements', EE which leads to the intercellular movements. In above example the EE are 16, which is also much higher and also grouping efficiency is $0.5955 \%$ and hence in order to minimize the intercellular movements. The following solution is suggested. Keeping only $11^{\text {th }}, 10^{\text {th }}, 12^{\text {th }}$ machines outside the cells, only one cell of all the other machines and parts may be formed. Which reduces outside entries of one's to 4 . The modified suggested solution is given in Fig. 3.

The other performance measures suggested in literature are also checked with respect to the modified solution and there values are calculated in this section.

ii) Grouping efficiency: Chandrasekharan and Rajagopalan $^{21}$ have proposed the grouping efficiency measure for the first time. The grouping efficiency $\eta$ is the average of $\eta_{1}$ and $\eta_{2}$.

$$
\begin{aligned}
& \eta_{1}=\frac{e_{d}}{\sum_{i=1}^{C} M_{l} N_{l}} \\
& \eta_{2}=1-\frac{e_{0}}{n x m-\sum_{i=1}^{C} M_{l} N_{l}} \\
& \eta=q \eta_{1}+(1-q) \eta_{2}
\end{aligned}
$$

Where, $\mathrm{n}$ is total no. of parts

$\mathrm{m}$ is total no. of machines.

$M_{l}$ the number of machines in the 1-th cell .

$N_{l}$ the number of parts in the 1-th cell.

$e_{d}$ the number of ' 1 ' in the diagonal blocks.

$e_{o}$ the number of ' 1 ' in the off diagonal blocks.

$q$ the weighting factor. $(0 \leq q \leq 1)$

$\mathrm{C}$ the number of cells.

Here, $\eta_{1}$ is the measure for the within group utilization, implies how much the machines of each cell handle the parts of the corresponding family. And the $\eta_{2}$ implies about the least inter cell movement of the parts and how few exceptional parts exists. These measures reflect different aspects of the grouping effectiveness. The $\eta$ is the measure of grouping efficiency. Larger the value of the efficiency the better is the grouping effectiveness becomes.

The value of $\eta$ ranges between 0 and 1 . For the purpose of numerical analysis the weighting factor, $q$, is taken as 0.5 implies both machine utilization and number of exceptional elements are equally important. The values for the solution suggested in figure 3.0 are $\eta_{1}=0.333, \eta_{2}=0.921$ and $\eta=62.7$ $\%$.

iii) Group efficacy: Chandrasekharan and Rajagopalan $^{22}$ have proposed the grouping efficacy, $\tau$ as,

$$
\tau=\frac{1-\varphi}{1+\phi}
$$

where, $\varphi=$ the ratio of number of exceptional elements to the total number of elements.

$$
\phi=\text { the ratio of } 0 \mathrm{~s} \text { ( blank spaces) in }
$$

the formed cell block to the total number of elements.

Therefore, $\varphi=4 / 106=0.0377$

$$
\begin{aligned}
& \phi=204 / 106=1.924 \\
& 0.9623 / 2.294=0.4194
\end{aligned}
$$

iv) Grouping measure: Machine utilization index $\left(\eta_{\mathrm{g}}\right)$ was proposed by Miltenburg and Zhang ${ }^{23}$. This measure gives the machine utilization in the cell.

$$
\eta_{\mathrm{g}}=\eta_{\mathrm{u}}-\eta_{\mathrm{m}}
$$

where $\eta_{\mathrm{u}}=e_{d /} e_{d^{+}} \mathrm{V}=102 / 102+(306-102)=0.33$

' $\mathrm{v}$ ' is voids in the cell. 


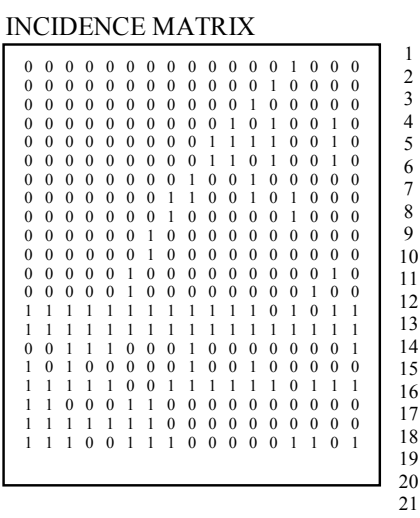

$\underset{\mathrm{a}}{\operatorname{MATRIX} \text { of 'Rij' }}$

$\begin{array}{lllllllllllllllll}0.000 & 0.000 & 0.000 & 0.000 & 0.000 & 0.000 & 0.000 & 0.000 & 0.000 & 0.000 & 0.000 & 0.000 & 0.000 & 0.200 & 0.000 & 0.000 & 0.000\end{array}$ $\begin{array}{llllllllllllllllll}0.000 & 0.000 & 0.000 & 0.000 & 0.000 & 0.000 & 0.000 & 0.000 & 0.000 & 0.000 & 0.000 & 0.000 & 0.200 & 0.000 & 0.000 & 0.000 & 0.000\end{array}$ $\begin{array}{lllllllllllllllll}0.000 & 0.000 & 0.000 & 0.000 & 0.000 & 0.000 & 0.000 & 0.000 & 0.000 & 0.000 & 0.000 & 0.143 & 0.000 & 0.000 & 0.000 & 0.000 & 0.000\end{array}$ $\begin{array}{llllllllllllllllll}0.000 & 0.000 & 0.000 & 0.000 & 0.000 & 0.000 & 0.000 & 0.000 & 0.000 & 0.000 & 0.143 & 0.000 & 0.143 & 0.000 & 0.000 & 0.125 & 0.000\end{array}$ $\begin{array}{lllllllllllllllllll}0.000 & 0.000 & 0.000 & 0.000 & 0.000 & 0.000 & 0.000 & 0.000 & 0.000 & 0.125 & 0.111 & 0.091 & 0.111 & 0.000 & 0.000 & 0.100 & 0.000\end{array}$ $\begin{array}{llllllllllllllllll}0.000 & 0.000 & 0.000 & 0.000 & 0.000 & 0.000 & 0.000 & 0.000 & 0.000 & 0.143 & 0.125 & 0.000 & 0.125 & 0.000 & 0.000 & 0.111 & 0.000\end{array}$ $\begin{array}{lllllllllllllllll}0.000 & 0.000 & 0.000 & 0.000 & 0.000 & 0.000 & 0.000 & 0.000 & 0.143 & 0.000 & 0.000 & 0.125 & 0.000 & 0.000 & 0.000 & 0.000 & 0.000\end{array}$ $\begin{array}{lllllllllllllllll}0.000 & 0.000 & 0.000 & 0.000 & 0.000 & 0.000 & 0.000 & 0.143 & 0.111 & 0.000 & 0.000 & 0.100 & 0.000 & 0.125 & 0.000 & 0.000 & 0.000\end{array}$ $\begin{array}{lllllllllllllllll}0.000 & 0.000 & 0.000 & 0.000 & 0.000 & 0.000 & 0.000 & 0.200 & 0.000 & 0.000 & 0.000 & 0.000 & 0.000 & 0.167 & 0.000 & 0.000 & 0.000\end{array}$

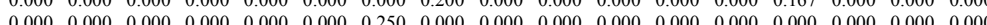
$\begin{array}{lllllllllllllllllllll}0.000 & 0.000 & 0.000 & 0.000 & 0.000 & 0.000 & 0.250 & 0.000 & 0.000 & 0.000 & 0.000 & 0.000 & 0.000 & 0.000 & 0.000 & 0.000 & 0.000\end{array}$ $\begin{array}{llllllllllllllllll}0.000 & 0.000 & 0.000 & 0.000 & 0.000 & 0.000 & 0.000 & 0.000 & 0.000 & 0.000 & 0.000 & 0.000 & 0.000 & 0.000 & 0.000 & 0.143 & 0.000\end{array}$ $\begin{array}{lllllllllllllllll}0.000 & 0.000 & 0.000 & 0.000 & 0.000 & 0.200 & 0.000 & 0.000 & 0.000 & 0.000 & 0.000 & 0.000 & 0.000 & 0.000 & 0.333 & 0.000 & 0.000\end{array}$ $\begin{array}{lllllllllllllllll}0.000 & 0.000 & 0.000 & 0.000 & 0.000 & 0.200 & 0.000 & 0.005 & 0.000 & 0.000 & 0.000 & 0.000 & 0.000 & 0.000 & 0.333 & 0.000 & 0.000\end{array}$ $\begin{array}{lllllllllllllllllllll}0.053 & 0.056 & 0.050 & 0.053 & 0.053 & 0.050 & 0.050 & 0.050 & 0.045 & 0.050 & 0.048 & 0.043 & 0.048 & 0.048 & 0.056 & 0.045 & 0.053\end{array}$ $\begin{array}{lllllllllllllllllll}0.053 & 0.056 & 0.050 & 0.053 & 0.053 & 0.050 & 0.050 & 0.050 & 0.045 & 0.050 & 0.048 & 0.043 & 0.048 & 0.048 & 0.056 & 0.045 & 0.053\end{array}$ $\begin{array}{lllllllllllllllllllll}0.000 & 0.000 & 0.125 & 0.143 & 0.143 & 0.000 & 0.000 & 0.000 & 0.100 & 0.000 & 0.000 & 0.000 & 0.000 & 0.000 & 0.000 & 0.000 & 0.143\end{array}$ $\begin{array}{lllllllllllllllllllll}0.167 & 0.000 & 0.143 & 0.000 & 0.000 & 0.000 & 0.000 & 0.000 & 0.111 & 0.000 & 0.000 & 0.100 & 0.000 & 0.000 & 0.000 & 0.000 & 0.000\end{array}$ $\begin{array}{llllllllllllllllllll}0.062 & 0.067 & 0.059 & 0.062 & 0.062 & 0.000 & 0.000 & 0.059 & 0.053 & 0.059 & 0.056 & 0.050 & 0.056 & 0.000 & 0.067 & 0.053 & 0.062\end{array}$ $\begin{array}{llllllllllllllllllllll}0.167 & 0.200 & 0.000 & 0.000 & 0.000 & 0.143 & 0.143 & 0.000 & 0.000 & 0.000 & 0.000 & 0.000 & 0.000 & 0.000 & 0.000 & 0.000 & 0.000\end{array}$ $\begin{array}{lllllllllllllllll}0.111 & 0.125 & 0.100 & 0.111 & 0.111 & 0.100 & 0.100 & 0.000 & 0.000 & 0.000 & 0.000 & 0.000 & 0.000 & 0.000 & 0.000 & 0.000 & 0.000\end{array}$ $\begin{array}{llllllllllllllllllll}0.091 & 0.100 & 0.083 & 0.000 & 0.000 & 0.083 & 0.083 & 0.083 & 0.000 & 0.000 & 0.000 & 0.000 & 0.000 & 0.077 & 0.100 & 0.000 & 0.091\end{array}$

Formed Component-Machine Cell/Cells:

CELL 1

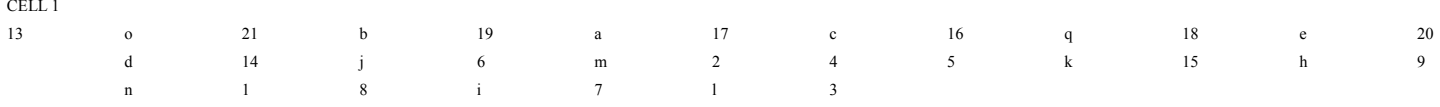

CELL 2

11

CELL 3

12

Resulting matrix by the proposed algorithm

Parts

\begin{tabular}{|c|c|c|c|c|c|c|c|c|c|c|c|c|c|c|c|c|c|c|}
\hline & $\mathbf{0}$ & $\mathbf{b}$ & $\mathbf{a}$ & $\mathbf{c}$ & $\mathbf{q}$ & $\mathbf{e}$ & $\mathbf{d}$ & $\mathbf{j}$ & $\mathbf{m}$ & $\mathbf{k}$ & $\mathbf{h}$ & $\mathbf{n}$ & $\mathbf{i}$ & $\mathbf{l}$ & $\mathbf{g}$ & $\mathbf{f}$ & $\mathbf{p}$ \\
\hline $\mathbf{1 3}$ & 1 & & & & & & & & & & & & & & & $\mathbf{1}$ & \\
\hline $\mathbf{2 1}$ & 1 & 1 & 1 & 1 & 1 & & & & & 1 & 1 & & & 1 & $\mathbf{1}$ & & \\
\hline $\mathbf{1 9}$ & & 1 & 1 & & & & & & & & & & & & $\mathbf{1}$ & $\mathbf{1}$ & \\
\hline $\mathbf{1 7}$ & & & 1 & 1 & & & & & & & & & 1 & 1 & & & \\
\hline $\mathbf{1 6}$ & & & & 1 & 1 & 1 & 1 & & & & & & 1 & & & & \\
\hline $\mathbf{1 8}$ & 1 & 1 & 1 & 1 & 1 & 1 & 1 & 1 & 1 & 1 & 1 & & 1 & 1 & & & $\mathbf{1}$ \\
\hline $\mathbf{2 0}$ & & 1 & 1 & 1 & & 1 & 1 & & & & & & & & $\mathbf{1}$ & $\mathbf{1}$ & \\
\hline $\mathbf{1 5}$ & 1 & 1 & 1 & 1 & 1 & 1 & 1 & 1 & 1 & 1 & 1 & 1 & 1 & 1 & $\mathbf{1}$ & $\mathbf{1}$ & $\mathbf{1}$ \\
\hline $\mathbf{1 4}$ & & 1 & 1 & 1 & 1 & 1 & 1 & 1 & 1 & 1 & 1 & 1 & 1 & 1 & $\mathbf{1}$ & $\mathbf{1}$ & $\mathbf{1}$ \\
\hline $\mathbf{6}$ & & & & & & & & 1 & 1 & 1 & & & & & & & $\mathbf{1}$ \\
\hline $\mathbf{2}$ & & & & & & & & & 1 & & & & & & & & \\
\hline $\mathbf{4}$ & & & & & & & & & 1 & 1 & & & & & & & $\mathbf{1}$ \\
\hline $\mathbf{5}$ & & & & & 1 & & & 1 & 1 & 1 & & & & 1 & & & $\mathbf{1}$ \\
\hline $\mathbf{9}$ & & & & & & & & & & & 1 & 1 & & & & & \\
\hline $\mathbf{1}$ & & & & & & & & & & & & 1 & & & & & \\
\hline $\mathbf{8}$ & & & & & & & & & & & 1 & 1 & 1 & 1 & & & \\
\hline $\mathbf{7}$ & & & & & & & & & & & & & 1 & 1 & & & \\
\hline $\mathbf{3}$ & & & & & & & & & & & & & & 1 & & \\
\hline $\mathbf{1 1}$ & & & & & & & & & & & & & & & 1 & & \\
\hline $\mathbf{1 0}$ & & & & & & & & & & & & & & & 1 & & \\
\hline $\mathbf{1 2}$ & & & & & & & & & & & & & & & & 1 & 1 \\
\hline
\end{tabular}

Figure 2. The Incidence matrix, analysis along with resulting matrix.

Journal of Mechanical Engineering, Vol. ME 43, No. 2, December 2013 Transaction of the Mechanical Engineering Division, The Institution of Engineers, Bangladesh 


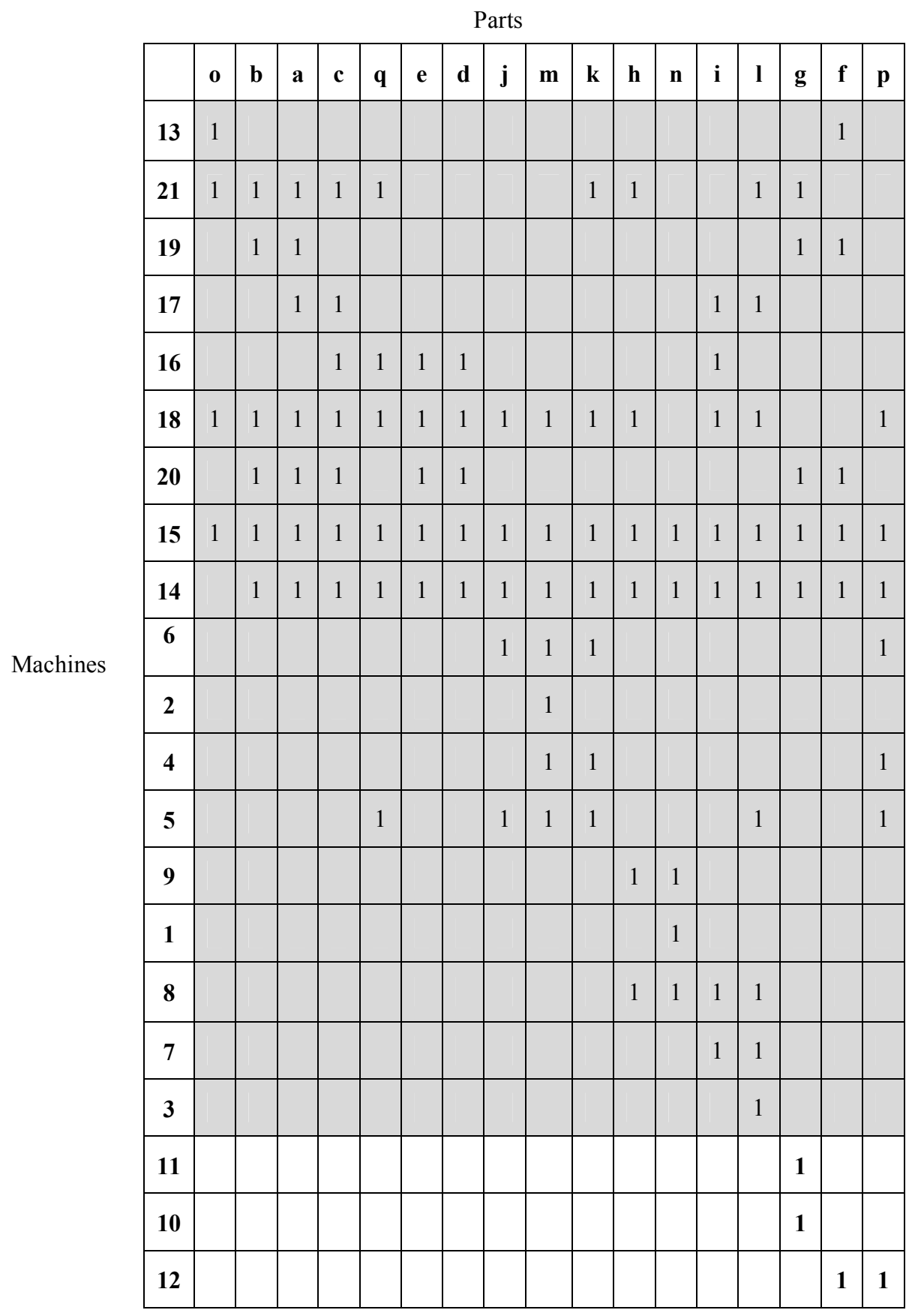

Figure 3. The modified solution.

$\eta_{\mathrm{m}}=1-e_{d / o}=1-102 / 106=0.0377$

' $\mathrm{o}$ ' is total number of $1 \mathrm{~s}$ in incidence matrix .

Therefore $\eta_{\mathrm{g}}=0.33-0.0377=0.2977$

v) Grouping capability index (GCI):

$$
G C I=1-e, o
$$

where, $e$ is number of exceptional elements in resulting matrix.

$o$ is total number of operations in the matrix.
Hsu ${ }^{24}$ excluded entries of 0 s from the calculation of group efficacy and efficiency

$$
G C I=1-4 / 106=0.9623
$$

vi) Grouping index (GI ): Nair and Narendran ${ }^{25}$ proposed a new measure of performance. The voids and exceptional elements were given same importance and considering the block digonalised area of solution they combined the above three 
measures and proposed a weighting factor, correction factor, and block diagonal space.

$$
\gamma=\frac{1-\alpha}{1+\alpha}
$$

where, $\alpha=\frac{q v+(1-q)(e-A)}{B}$

$B$ is block digonalised area.

$A=0$ for $e \leq B$

$A=e-B$ for $e \triangleright B$

The values of $\alpha$ and $\gamma$ lie between 0 and 1 .

Assuming the weighting factor $q=0.5$

$$
\begin{aligned}
& \alpha=\frac{0.5 \times 204+(1-0.5)(4-0)}{306}=0.3398 \\
& \gamma=\frac{1-0.3398}{1+0.3398}=0.4927
\end{aligned}
$$

The functional arrangement of machines and components in the plant is shown in Fig. 4. All the above performance measures are checked for functional arrangement in the plant as well. The shaded area of matrix in Fig. 4 depicts operations which are conducted in the premises of ' $\mathrm{M} / \mathrm{s}$ Kinetic Gears' and non - shaded portion of matrix indicates operations which are carried outside the 'M/s Kinetic gears premises through manual transportation of components.

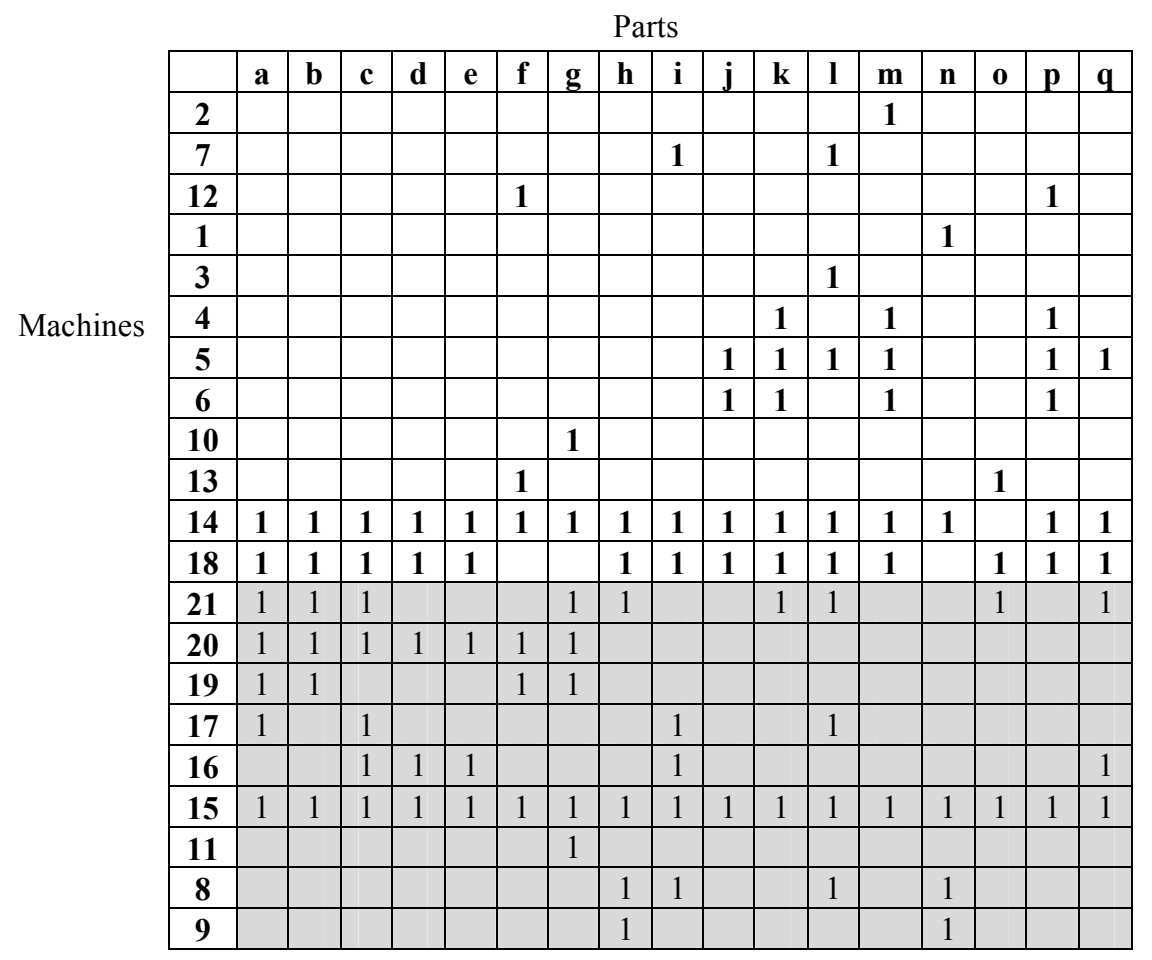

Figure 4. The existing arrangement of machines at 'M/s Kinetic Gears'.

i. Total number of 'Exceptional Elements', EE , from the Fig. 4 is 53 ( The number of $1 \mathrm{~s}$ in the non shaded area of matrix in Fig. 4) .

ii. Grouping efficiency:

$\eta_{1}=0.3464, \quad \eta_{2}=0.7401 \quad$ and $\eta=54.32 \%$

iii . Grouping efficacy:

$$
\begin{gathered}
\varphi=53 \div 106=0.5 \quad \phi=100 \div 106=0.9433 \\
\tau=0.257
\end{gathered}
$$

iv. Grouping measure:

Machine utilization index, $\eta_{\mathrm{g}}=\eta_{\mathrm{u}}-\eta_{\mathrm{m}}$ where $\eta_{\mathrm{u}}=e_{d /} e_{d+} \mathrm{V}=53 /(53+100)=0.346$

$$
\eta_{\mathrm{m}}=1-e_{d / o}=1-53 / 106=0.5
$$

Therefore $\eta_{\mathrm{g}}=-0.154$

( $\eta_{g}$ value lies between -1 to 1 and $\eta_{u}, \eta_{m}$ values lie between 0 and 1 )

v . Grouping capability index (GCI):

$$
G C I=1-e_{,} o=1-53 / 106=0.5
$$

vi. Grouping index (GI ):

$$
\text { Assuming } q=0.5, \quad \alpha=0.5 \text {, }
$$$$
\gamma=0.333
$$

The comparison of results is done in the following section. 
Table 3. The results obtained for existing and due to proposed solution

\begin{tabular}{|c|l|c|c|}
\hline S. no. & Performance measure & $\begin{array}{l}\text { Values for functional } \\
\text { layout. }\end{array}$ & $\begin{array}{l}\text { Values due to } \\
\text { proposed solution. }\end{array}$ \\
\hline 1 & Number of exceptional elements. & 53 & 04 \\
\hline \multirow{2}{*}{2} & $\begin{array}{l}\text { i. Within group utilization. } \\
\text { ii. Inter cell movement of the parts. } \\
\text { iii. Grouping efficiency. }\end{array}$ & $\begin{array}{c}\eta_{1}=0.3464 \\
\eta_{2}=0.7401 \\
\eta=54.32 \%\end{array}$ & $\begin{array}{c}\eta_{1}=0.33 \\
\eta_{2}=0.921 \\
\eta=62.7 \%\end{array}$ \\
\hline 3 & Grouping efficacy. & 0.257 & 0.4194 \\
\hline 4 & Grouping measure,(GM). & -0.154 & 0.2977 \\
\hline 5 & Grouping capability index, (GCI). & 0.5 & 0.9623 \\
\hline 6 & Grouping index, (GI). & 0.333 & 0.4927 \\
\hline
\end{tabular}

\section{COMPARISON OF RESULTS}

The results obtained on performance evaluation in case of existing layout of ' $\mathrm{M} / \mathrm{s}$ Kinetic gears' and modified solution is given in Table 3 .

\section{CONCLUSIONS}

The results obtained in the previous section clearly show the scope of improvement is possible due to proposed method of machine-component grouping. In summerised way it is concluded that,

I. Performance measure 1 entail much reduction in the intercellular movements can be achieved through reduction of 'EE'.

II. Performance measure 2 shows the machine utilization shall remain same but remarkable improvement in intercellular movements can be made. This leads to increase in grouping efficiency amazingly.

III. Much improvement is seen in grouping efficacy as indicated by performance measure 3 .

IV. Grouping capability index (GCI), Grouping measure (GM), Grouping index (GI ) have improved in the modified solution.

$\mathrm{V}$. Due to dissimilar processing requirements of parts the case is involved with large number of exceptional parts.

VI. Due to large exceptional parts the precise grouping of machine and components is possible to a smaller extent as expected.

VII. The method clusters the machine components well in case of situation involving large exceptions also as indicated via improved values of efficiencies and performance measures.

\section{RECOMMENDATIONS}

It is recommended that the present machine arrangement tends to increase the intercellular movements that is manual transportation of parts impair the overall efficiency and in view of reducing them the machines are parts must be as close as possible i.e. parts need to be manufactured in single unit due to diverse processing requirements as suggested via modified solution in Fig. 3. The machines can be physically arranged as suggested via modified solution in Fig. 3 for improving the productivity.

\section{REFERENCES}

1. Adil, G.K., Rajamani, D., and Strong, D., 1996, "Cell Formation Considering Alternate Routings," Int. J. of Production Research, 34(5), pp. 13611380 .

2. Zhao, C., and Wu, Z., 2000, "A Genetic Algorithm for Manufacturing Cell formation With Multiple Routes and Multiple objectives," Int. J. of Production Research, 38(2), pp. 385-395.

3. Kim, C.O., Baek J.G., and Baek J.K., 2004,“A Two-Phase Heuristic Algorithm for Cell Formation Problems Considering Alternative Part Routes and Machine Sequences", Int. J. of Production Research, 42(18), pp. 3911-3927.

4. Hachicha, W., Masmoudi F., and Haddar M., 2006 "A Correlation Analysis Approach of Cell Formation in Cellular Manufacturing System with Incorporated Production Data," Int. J. of Manufacturing Research, 1 (3), pp. 332-353.

5. Megala, N., Rajendran C., and Gopalan R., 2008, "An Ant Colony Algorithm for Cell-Formation in Cellular Manufacturing Systems', Euro. J. of Industrial Engineering, 2(3), pp. 298 -336.

6. Praveen, P., Chowdary, S.G., Boppana,V., and Deshmukh, P.P, 2009. "A New Approach For Formation of Virtual Cells', Int. J. of Manufacturing Research, 4(2), pp. $171-188$.

7. Co, K.C., and Egbelu, P.J., 2003, "Virtual cell formation", Int. J. of Production Research, 41(11), pp. 2365- 2389.

8. Sofianpoulou, S., 2010 "Formation of Manufacturing Cells in Group Technology Using A Genetic Algorithm Approach", Int. J. of Industrial and Systems 1 Engineering, 5(2), pp. 212 -225.

9. Manzini, R. Bindi, F., and Pareschi, A., 2010, "The Threshold Value of Group Similarity in the Formation of Cellular Manufacturing Systems", Int. J. of Production Research, 48(10), pp. 30293060 .

10. Jayachitra, R., and Prasad, P.S.S., 2011 "Investigations on Performance of Process, 
Cellular and Virtual Cellular Layouts", Int. J. of Business and Systems Research, 5(4), pp. 325-340. 11. Jayachitra, R., and Prasad P. S. S., 2010, "Design and Selection of Facility Layout Using Simulation and Design of Experiments", Indian J. of Science and Technology, 3(4), pp. 437-446.

12. Kumar, M. S., Islam, M.N., Lenin ,N. Kumar, V., and Ravindran, D., 2011,“A Simple Heuristic for Linear Sequencing of Machines in Layout Design", Int. J. of Production Research, 49(22), pp. 6749- 6768 .

13. Ying, K.C., Lin, S.W., and Lu, C.C., 2011, "Cell Formation Using A Simulated Annealing Algorithm with Variable Neighbourhood", Euro. J. of Industrial Engineering, 5(1), pp. 22 -42.

14. Mahdavi, I. ,Aalaei , A., Payder, M. M., and Solimanpur, M., 2011, "Multi-Objective Cell Formation and Production Planning in Dynamic Virtual Cellular Manufacturing Systems", Int. J. of Production Research,49(21), pp. 6517-6537.

15. Farahani, H.M., and Hosseini, L., 2011, "An Ant Colony Approach for the Machine - Part Cell Formation Problem", Int. J. of Computational Intelligence Systems, 4(4), pp. 486 - 496.

16. Mathur, A., and Mittal, M.L., 2012, "Improving Productivity in Indian SMEs," Production Planning and Control, 23(10-11), pp. 754-768.

17. Elbenani, B., and Ferland, J. A., 2012, "An Exact Method for Solving the Manufacturing Cell Formation Problem", Int. J. of Production Research,50(15), pp. 4038 - 4045.

18. Sharam, A., Ismail, N., Tang, S.H., Mohd. Ariffin, M.K.A., and Firoozi, Z., 2012 "The Reconfiguration Issue of Stochastic Facility Layout Design in Cellular Manufacturing Systems", Int. J. of Services and Operations Management, 11(3), pp. 255-256.
19. Saravanan, M., and Arulkumar, P.V., 2013, "Design and Optimisation for Fixed Area Cellular Layout Problems using GA And SAA", Int. J. of Innovation and Sustainable Development, 7(1), pp. 91-109.

20. Masmoudi, F., and Hachicha, W.,2013, "A Simulation Approach for Cellular Manufacturing Design from Initial Cell Formation Solutions", Int. J. of Manufacturing Research,8(1), pp. 85-102.

21.Chandrasekharan, M.P., and Rajagopalan, R., 1986(a), "An Ideal Seed Non- Hierarchical Clustering Algorithm for Cellular Manufacturing", International Journal of Production Research, 24, pp.451-464.

22. Chandrasekharan, M.P., and Rajagopalan, R. , 1986(b), "MODROC: An Extension of Rank Order Clustering for Group Technology", Int. J. of Production Research, 24, pp.1221-1233.

23. Miltenburg, J., and Zhang , W., 1991, "A Comparison of Nine Well Known Algorithms for Solving the Cell Formation Problem in Group Technology", J. of Operations Management, 10, pp.44-72.

24. Hsu, C.P., 1990, "Similarity Coefficient Approaches to Machine - Component Cell Formation in Cellular Manufacturing: A Comparative Study", Ph.D. thesis Department of Industrial and Manufacturing Engineering, University of Wisconsin-Milawaukee.

25. Nair, G.J.K., and Narendran, T.T., 1996, "Grouping Index: A New Quantitative Criterion for Goodness of Block-Diagonal Forms in Group Technology", Int. J. of Production Research, $34(10)$, pp. $2767-2782$. 